\title{
化学プロセス産業におけるリスクアセスメント及びリスク低減措置 の検討に関する調査研究†
}

島田 行 恭*1 北島 禎 二*2 木 村 新 太*3

\begin{abstract}
リスクアセスメント（Risk Assessment；以下，RA と略す）の目的は，事故・災害発生を防止するためのリ スク低減措置を事前に検討・実施するために，対象となるプラント（設備）や作業環境などに潜在するハザード に対するリスクを評価することである．RA に基づく労働災害の未然防止を図ろうとする行政施策の下，「RA 等 を実施している」とする事業場の割合は増えている。しかしながら, 実際の操業現場などで実施されている RA 等では, RAの目的, 評価方法, 評価結果に基づくリスク低隇措置の検討などが正しく理解されていない場合が多 く，真に有効なリスク低減措置が実施されているとは言い難い.

本調査研究では, 大手, 中小規模十数社の工場見学を通じての安全管理担当者への聞き取り調查と, 化学工 学会安全部会におけるワーキンググループ活動での企業有識者との議論を通じて, 化学プロセス産業（石油, 石 油化学, 化学などを含む) の操業現場を対象とした, RA 及びリスク低減措置の検討・実施と, プラントに潜在す る危険性情報共有に関する現状と課題についてまとめた，また，それらの課題を解決することを目的とした，プ ラントライフサイクルエンジニアリングによる統合的リスクマネジメントの進め方の検討について報告する.

キーワード: リスクアセスメント, リスク低減措置, 労働安全, プロセス安全, 独立防御層
\end{abstract}

\section{1 はじめに}

化学プロセス産業の各事業場・プラントでは, 自主的 な安全管理活動の実施が要求され, リスクアセスメント

(Risk Assessment ; 以下, RA と略す), 危険予知訓練 (KYT) , ヒヤリハット情報の収集, 体感教育など, 様々 な活動を行っている．長期的に見れば，化学物質に起因 する爆発・火災事故による労働災害発生件数は減少傾向 にあるが，ここ数年，事業場外の周辺地域住民をも巻き 込むような大事故が多発している ${ }^{11}$.

プラントでは, 取り扱い物質の異常反応, 設備の不具 合, 人為的エラーなど, 様々な要因が事故の直接的原因 となり得る。また，安全管理体制に不備があること， RA 及びリスク低減措置の検討・実施が不十分であること, 安全管理のための作業や業務に関する知識・情報共有が 不十分であること，緊急時対応を含めた安全管理の規範 となるべき標準・基準が整備されていないことなどが事 故の背景要因として指摘されている ${ }^{2)}$.

本調查研究では, 大手, 中小規模十数社の工場見学を 通じての安全管理担当者への聞き取り調査と, 化学工学 会安全部会におけるワーキンググループ活動での企業有 識者との議論を通じて, RA 及びリスク低減措置の検 討・実施と，プラントに潜在する危険性情報共有に関す る現状と課題についてまとめた．またこれらの課題を解 決することを目的としたプラントライフサイクルエンジ ニアリングよる統合的リスクマネジメントの進め方の検 討について報告する.

\footnotetext{
†原稿受付 2013 年 03 月 11 日

$\dagger$ 原稿受理 2013 年 06 月 26 日

*1 (独)労働安全衛生総合研究所 化学安全研究グループ

*2 東京農工大学大学院 工学研究院

*3 (独)海上技術安全研究所 海洋リスク評価系

連絡先 : ₹ 204-0024 東京都清瀬市梅園 1-4-6

(独)労働安全衛生総合研究所 化学安全研究グループ 島田行恭*1

E-mail: shimada@s.jniosh.go.jp
}

\section{2 リスクアセスメント（RA）等に関する現状と課題 1）化学物質等による危険性又は有害性等の調査等に関 する指針}

労働安全衛生法第 28 条の 2 では労働災害防止を目的 としてRA を実施することが努力義務とされている．さ らに, 労働安全衛生法第 28 条の規定に基づいて『化学 物質等による危険性又は有害性等の調查等に関する指 針』が公表されている.この指針の第 10 項(1)では, リ スク低減の考え方として，1）本質安全対策，2）工学的 対策，3）管理的対策，4）個人用保護具の使用，の優先 順位に従ったリスク低減措置の検討と実施を求めている,

また, 労㗢安全衛生マネジメントシステムの運用にお いても,「危険源の継続的特定, RA 及び必要な管理策の 決定の手順を確立し, 実施し, 維持すること」が要求さ れている3).

2）労衝安全衛生基本調査（アンケート結果）より

平成 22 年労衝安全衛生基本調査のアンケート結果 ${ }^{4)}$ によると, 大規模事業場のほとんど (約 9 割) は「RA を 実施している」と回答し，「職場に存在するリスクの情 報を共有することができた」，「本質安全化に向けた対 策が実施できた」などの効果が報告されている。一方, 中小規模事業場では，「十分な知識を持った人材がいな い」，「実施方法が判らない」などの理由から，「RAを 実施していない」と回答している事業場が多い.

RA の目的は事故・災害発生を事前に防止することで あるが，上記アンケート結果に示されるように必ずしも $\mathrm{RA}$ 及びリスク低隇措置の検討・実施が的確に実施され ているとは言えず, 時間と労力を掛けて RAを実施して も事故の発生防止に寄与していない場合がある. 


\section{3）製造業における RA 等に関する問題}

製造業における RA 等実施を妨げている要因と RA 等 実施に関する問題について以下に示す ${ }^{1}$.

（1） RA 等の実施を妨げている要因

RA 等の的確な実施を妨げている要因としては以下の ようなことがあると考える。

(1) RA は手間が掛かるものと認識されている.

・RA 実施に関する参考資料や書籍の多くは,「経営トッ プによる RA 導入宣言」,「実施体制の確立」,「関係情 報（資料）の収集」，「RA 教育の実施」などを $\mathrm{RA}$ 導 入時必須事項として挙げている. このため, 予め多く の準備作業をしなければ RA を実施することはできな いと解釈され，導入を試みようとした段階で「RA は 手間の掛かるもの」と判断し，現場では「RAのよう な面倒なことをやっている暇は無い」と諦めてしまう こともある.

(2) 現場に負担を掛ける割に効果が感じられない.

・安全管理担当者は RA 等実施による「先取り」安全管 理の有用性を説くが，すぐに効果が現れず，現場では その意義が理解されない.

(3) ヒヤリハット情報の収集と共有, KYT なども実施し ており,これで安全性に関しては十分であると考える.

・これらの活動は現場作業者の直感に依存するものであ り，必ずしも潜在するハザードを網羅的に発見するも のではない.

(4)一度 RAを実施した後は放置されている.

・RA 実施結果が紙媒体で記録として残されただけで, 具体的なリスク低減措置が実施されないままとなって いる場合がある.

\section{(2) $\mathrm{RA}$ 等の実施に関する問題}

$\mathrm{RA}$ 等の的確な実施に対して，以下のような問題があ る.

(1) 潜在的なハザードを見付けられない.

- 現場診断, 事故事例／ヒヤリハット情報の活用, KYT などは作業現場での八ザード発見の助けにはなるが， 作業者の経験などへの依存度が大きく, 潜在ハザード を漏れなく抽出するのは難しい.

(2)「ハザード発生頻度」と「ハザードによる影響の大き さ」をどのように評価し，リスクレベルを決定すれば 良いか判らない。

・ハザード発生頻度を求めるためのデータが揃っていな い.

・ハザードによる影響を客観的に定性・定量評価するこ とが難しい.

(3)リスクはより低く見積もりたいと考える.

・リスクマトリクス法を用いる場合，ハザード発生頻度 とハザードの影響をどのように定義するかにより，リ スクレベルが変動してしまう。

・適切なリスク低減措置が検討・実施されていないにも かかわらず,「リスクレベルが下がる」と結論付けてい

1 参考文献 5)なども参照
る場合がある。「監視体制を強化すること（管理的対 策)」は「災害発生の可能性」や「危険に近づく頻度」 を下げることはあっても,「災害の重大性」を低くする ことに直接的には繋がらない，例えば，表 1 に示すよ うに,「ガス濃度を定期的に測定する環境を整備し, 標 準化する (毎月測定)」としても, 原材料や反応条件な ごが同じであれば, 災害発生時の重大性は変わらない。 このように, リスク低減措置の検討・実施が的確に実 施されず，時間と労力を掛けて RAを実施しても事故 の発生防止に寄与していない場合がある.

(4) ハザードによる深刻な影響が軽視されてしまう.

・頻度×影響としてリスクが見積もられた場合, 染意的 な定量化などによって頻度が (影響に対して相対的に) 極端に低い值に設定されてしまい, 影響が致命的で深 刻なものであってもリスクレベルが低いと判定され， ハザードの深刻さが隠されてしまう2。

・本来は許容できないほどのリスク領域であっても,「発 生頻度【低】の場合, ハザードは起こりえないから大 丈夫」と判断され，ハザードによる影響を緩和するた めの対策が検討されなくなる.

(5) 現状のリスク低減措置を信頼し過ぎている.

・既に実施されているリスク低減措置は異常発生時（緊 急時）に必ず機能すると考えているが，リスク低減対 策そのものがメンテナンスされていなかったか, そも そもリスク低減措置が不適切な場合もある.

(6) ALARP (As Low As Reasonably Practice) 領域の 意味が間違って解釈されている.

・現状のリスク領域が ALARP 領域（図 1）にある場合, 残留リスクが許容可能な無視しうるリスクと同程度と 捉えられ，ハザードの存在も忘れられてしまう.

・リスク領域を下げるための有効な対策が無い，または コスト面も含めて容易に対策が実施できないまま，

ALARP 領域にあると判断された場合，目標とするリ スク領域を満足していないにもかかわらず,「できる限 りの対策を実施したのでこれ以上は不要」と解釈して しまう。

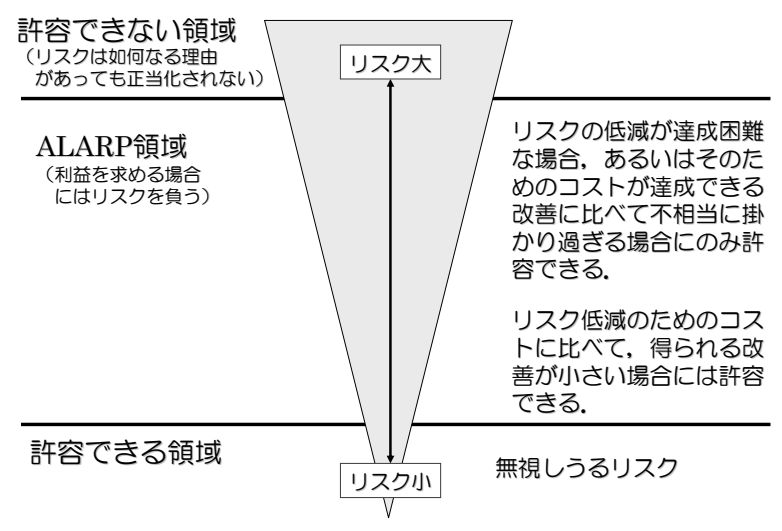

図 1 ALARP の原則

2 平成 23 年 3 月の大震災以降, よりシビアなリスク評価を行うことが 求められるようになっている，特に八ザード発生による影響の評価 では，具体的な対策が実施されない限り，リスクレベルは下がらな いような仕組みを導入する企業もある。 
表 1 正しいリスク評価？（あるRA 実施事例より）

\begin{tabular}{|c|c|c|c|c|c|c|c|c|c|c|c|c|c|c|c|}
\hline \multirow[t]{2}{*}{ No } & \multirow{2}{*}{$\begin{array}{l}\text { 災害原因 } \\
\text { (想定も含 } \\
\text { む) }\end{array}$} & \multirow[t]{2}{*}{$\begin{array}{c}\text { 災害が発生す } \\
\text { るプロセス }\end{array}$} & \multicolumn{6}{|c|}{$\begin{array}{l}\text { リスク評価 } \\
\text { (現状) }\end{array}$} & \multirow[t]{2}{*}{$\begin{array}{c}\text { リスク } \\
\text { 低減対策 }\end{array}$} & \multicolumn{6}{|c|}{$\begin{array}{c}\text { リスク評価 } \\
\text { (リスク低減措置実施後) }\end{array}$} \\
\hline & & & $\begin{array}{l}\text { 災 } \\
\text { 害 } \\
\text { の } \\
\text { 重 } \\
\text { 大 } \\
\text { 性 }\end{array}$ & $\begin{array}{l}\text { 災 } \\
\text { 害 } \\
\text { 発 } \\
\text { 生 } \\
\text { の } \\
\text { 可 } \\
\text { 能 } \\
\text { 性 }\end{array}$ & $\begin{array}{l}\text { 危 } \\
\text { 険 } \\
\text { に } \\
\text { 近 } \\
\text { づ } \\
< \\
\text { 頻 } \\
\text { 度 }\end{array}$ & $\begin{array}{l}\text { 合 } \\
\text { 計 } \\
\text { 点 }\end{array}$ & $\begin{array}{l}\text { リ } \\
\text { ス } \\
\text { ク } \\
\text { レ } \\
\text { 心 } \\
\text { ル }\end{array}$ & $\begin{array}{l}\text { 順 } \\
\text { 位 }\end{array}$ & & $\begin{array}{l}\text { 災 } \\
\text { 害 } \\
\text { の } \\
\text { 重 } \\
\text { 大 } \\
\text { 性 }\end{array}$ & $\begin{array}{l}\text { 災 } \\
\text { 害 } \\
\text { 発 } \\
\text { 生 } \\
\text { の } \\
\text { 可 } \\
\text { 能 } \\
\text { 性 }\end{array}$ & $\begin{array}{l}\text { 危 } \\
\text { 険 } \\
\text { に } \\
\text { 近 } \\
\text { ご } \\
< \\
\text { 頻 } \\
\text { 度 }\end{array}$ & $\begin{array}{l}\text { 合 } \\
\text { 計 } \\
\text { 点 }\end{array}$ & $\begin{array}{l}\text { リ } \\
\text { ス } \\
\text { ク } \\
\text { レ } \\
\text { 心 } \\
\text { ル }\end{array}$ & $\begin{array}{l}\text { 順 } \\
\text { 位 }\end{array}$ \\
\hline 2 & $\begin{array}{l}\text { 装置 A 内でガ } \\
\text { スが滞留しや } \\
\text { すく, 着火の } \\
\text { 恐れがある }\end{array}$ & $\begin{array}{l}\text { 装置 } \mathrm{A} \text { 内ガス } \\
\text { 濃度が突然上 } \\
\text { 昇し, 爆発する } \\
\text { 可能性がある }\end{array}$ & 10 & 4 & 3 & 17 & IV & & $\begin{array}{l}\text { ガス濃度を定期的 } \\
\text { に測定する環境を } \\
\text { 整備し，標準化す } \\
\text { る(毎月測定) }\end{array}$ & 3 & 2 & 1 & 6 & I & \\
\hline
\end{tabular}

\section{4）化学プロセス産業における RA 等の課題}

製造業の中でも化学プロセス産業は, 化学物質の反応 挙動などを含んだ危険性を正確に評価することが難しく， 真に効果のあるリスク低減措置の検討が為されにくい. プラントに対する RA としては, 爆発・火災防止のため の化学物質 RA, プラント設備の安全設計のための設備 $\mathrm{RA}$, 作業者の安全確保のための作業安全 RA を実施する 必要がある。これら三つの RA 及びリスク低減措置の検 討・実施を統合的に実施することで，労働災害発生防止 だけでなく，プロセス災害発生防止と事故・災害が発生 した場合の被害の局限化を可能とするリスク低減措置の 検討を行うことができる.

化学プロセス産業の事業場・プラントにおける RA 等 の実施に関する課題を以下に示す.

(1) 多くの企業が「RA を実施している」と回答してい るが，実際には上記三つの RAのうち何れか一つを実 施しているだけの事業場も多い.

・上記三つの RA を全て実施していなければ, 化学物質 そのものの危険性が認識されていない場合, プラント 設備へのリスク低減措置の検討が不十分である場合, 労働災害を防止するための作業環境が整備されていな い場合がある.

・ 三つの RA 及びリスク低減措置の検討・実施を統合的 に行っていないと, 例えば, 化学物質 RA では爆発・ 火災の三要素 (可燃物, 酸素, 着火源) の有無のみに 焦点が当てられ, 設備トラブルや現場作業員の介在 (ヒ ューマンファクター) などに関するリスクが考慮され ない場合がある。

(2) 化学物質の挙動の把握には専門的知識を必要とする.

・目に見えない化学物質とその反応・挙動の危険性は八 ザードとして認識されにくい.

・現場の作業環境は必ずしも毎日同じではなく, 条件に よっては, 生産や安全に影響を与える場合もある.

・作業者の服装なども関係する静電気発生の問題なども 考慮する必要がある.

(3) 事業場毎, プラント設備毎に（バッチプラントでは 処理毎にも）取り扱い物質やその特性が異なり，他社 での事例（RA 等実施結果，事故事例などを含む）を 直接, 参考にすることが難しい.
・多くの場合, 物質の処理方法, 反応条件などのノウハ ウ，ノウホワイは公開されない.

(4)リスク低減措置として, 本質安全対策は難しく, 工 学的対策は経営面からもできるだけ避けたいと考えら れ，的確な RA 及びリスク低減措置検討・実施の妨げ となる。

・ハザード自体を取り除くことができず（本質安全対策 を実施せず), マニュアルの整備や点検回数を増やすな どの管理的対策のみを実施した場合には，ハザードの 発生確率を減らすことはできても，八ザードの影響そ のものは緩和されていない.

・マニュアルの整備などの管理的対策を実施することで 十分と結論付けられる，そのため，多くの事故が管理 ミスなどのヒューマンエラーであると結論付けられて しまう。

・安全インターロックシステムや安全弁設置などの工学 的対策は正常運転時も含めて常に作動可能となってい ることを確認しておくことなどが重要であるが，一度 設置されるとメンテナンスが行われていないままとな っている場合がある。

・長期的な化学品の製造事業を行う場合, 初期投資とし て工学的な対策を講じることが可能であるが，短期的 な化学品の製造請負などの事業では, 化学品に応じて プロセスの変更が頻繁に行われるため, 工学的対策へ の投資が避けられる場合がある.

(5) プラント設備の設計・建設担当と操業事業場が異な る.

・特に中小規模事業場では，プラント設備は他のエンジ ニアリング会社などにより設計・建設される場合が多 いが，建設されたプラントの詳細なプロセス安全情報 （設計ノウハウ，ノウホワイなど）まで現場作業者に 伝えられることは稀である.

・大規模事業場においても，プラント設計は他社または 他部署が担当している場合があり, 安全設計に関する 論理的な情報までは伝えられない（同じ社内でも部署 が違えば機密事項となることがある).

(6) 現場での労働災害防止だけでなく, プラント設備, 事業場内外への減災対策も重要となる. 
・事業場内での緊急時対応策の立案だけでなく, 事業場 外 (社会) に与える影響も考慮する必要がある.

(7) 設備保全に関わる RA 等実施や操業条件変更に伴う RA 等実施も必要となる.

・設備の長期的使用による劣化や社会的・経済的背景の 変化に伴う操業条件の変更などに対しても的確なタイ ミングで RA 等を実施する必要がある（変更管理に関 する課題については5）でも説明).

(8) 機械類の安全性を確保するための国際標準規格であ る ISO12100 を基本的な枠組みとして参照することは できるが，個別レベルでは化学プロセス産業の特性に 合わせた規格となっていない.

・化学プロセス産業では, 取扱物質, 反応条件, 操作条 件などが多様化しており，それらが原因となってプラ ント設備などに及ぼす影響は更に多様なものとなる。 そのため, 安全性・危険性に関寸る標準化が進んでい ない.

(9) 複数の省庁における法規制への対応が必要とされる. ・労働安全衛生法, 高圧ガス保安法, 消防法などへの対 応を要求されるが,これらの法規制に対応することが, 爆発・火災防止から減災対策までを含めた統合的なプ ロセス安全を実現する仕組みとは一致していない.

(10) 化学プロセスの爆発・火災防止及び減災対策の実施 例を紹介した資料はほとんどない.

・従来の RA 等実施事例集などで紹介されている事例に は化学物質の挙動, プラント設備, 作業などに関する リスク評価方法，対策が含まれていない場合が多い。

\section{5）変更管理と RA}

化学プロセス産業では, 原材料や触媒の変更, 操作条 件の変更，プラント設備の改造・改良，作業者の配置変 更などが行われた際の「変更管理」が課題となっている. 特に現場では,「変更している(いつの間にか変更されて (る)」という認識が無く, そのため, RA が実施されず, リスク低減措置が検討・実施されないままとなっている 場合が多い.

労働安全衛生規則第 24 条の 11 ，及び「化学物質等に よる危険性又は有害性等の調査等に関する指針」の第 5 項目では，次のような変更を伴う場合には RA を実施す ることとされている.

ア）化学物質等に係る建設物を変更するとき

イ）化学設備等に係る設備を変更するとき

ウ）化学物質等である原材料を変更するとき

エ）化学設備等に係る作業方法又は作業手順を変更する とき.

オ）その他

OHSAS18002；2008 6)の 4.3.1.5「変更のマネジメン 卜」では，変更管理の実施時期などについて，次のよう に述べており，RA 及びリスク低減措置の検討・実施が 重要であるとしている.
組織は, OH\&S 危険源及びリスクに作用する又は影響 を及ぼす可能性のあるいかなる変更も管理し，マネジメ ントするとよい，これらの変更には，組織体制，要員， マネジメントシステム, プロセス, 活動, 原材料の使用 などに対する変更を含む. そのような変更については, その実施に先立って，危険源の特定及びリスクアセスメ ントを適用して評価するとよい.

組織は, 組織における現行の作業, 製品, サービス又 は供給者などの変更と同様に, 設計段階において新規の プロセスや作業に関する危険源及び潜在的なリスクを考 慮するとよい. 次の事項は, 変更のマネジメントのプロ セスを始めるべき状態の例である.

一新規又は変更された技術(ソフトウェアを含む), 設備, 施設，作業環境

一制定又は改訂された手順書, 作業慣行, 計画, 使用又 は規格

一異なる種類又は等級の原料

一請負者の使用を含むサイトの組織体制及び人員配置の 著しい変更

一安全衛生装置／設備又は管理策の変更

変更のマネジメントプロセスは，新規又は変更された いかなるリスクも受容できることを確実にするために,

以下のような疑問に対して考慮するとよい.

一新しい危険源が作り出されるか?

一新しい危険源に関連するリスクは何か?

一その他危険源からのリスクに変化はあるか?

一その変更は現行のリスク管理策に悪影響を及ぼすこと があるか?

一有用性, 受容性, 及び直近, 長期双方のコストに配慮 し，最も適切な管理策が選ばれているか?

その他, 高圧ガス保安法, 米国 OSHA/PSM 7), 米国 化学工学会 (AIChE) の化学プロセス安全センター (CCPS: Center for Chemical Process Safety) のガイ ドライン 8)などでも変更管理の重要性を認め，該当する 変更を実施する場合には必ず RA 及びリスク低減措置の 検討・実施を行うことを要求している ${ }^{9)}$.

\section{3 潜在する危険性・有害性に関する情報共有の課題}

化学プロセスでは様々な化学物質を原材料や触媒など として用い，製品を製造する. 行政対応としては, 国連 勧告 (GHS ; The Globally Harmonized System of Classification and Labelling of Chemicals）や厚生労働 大臣告示などで, 化学物質の危険性・有害性情報をラベ ル表示することを義務付けている.

製品・プロセスの研究・開発の際に, 安全・安定に製 造するための反応条件や操作条件だけでなく, 製造プロ セスに潜在する危険性に関する多くの情報が得られる. またプラント設備の安全設計の際には, 様々な RA 手法 を用いて設備のどこにどのような危険源が存在するかが 洗い出され，その結果に基づくリスク低減措置の検討が 為される. この時, リスク低減措置が実施されていない 
部分や実施されてはいるものの依然としてリスクの大き な部分（残留リスク）についての危険性情報も把握され ている. しかしながら, これらの危険性に関する情報（知 見）は，実際に操業現場で働く作業者（運転員や保全員） に提供されておらず,「なぜそのような作業（操作）を行 うのか（いわゆるノウホワイ）」，あるいは「何をしたら 危険か」といったことを作業者が認識していない場合が 多い.

中小規模事業場では，原材料を受け入れ，製造のみを 実施するような業務形態の場合もある. この時, 受入原 材料や反応に関する危険性情報を把握していなかったり， さらに製造に用いるプラント設備が他のエンジニアリン グ会社や装置メーカーにより建設されている場合には, プラント設備に潜在する危険性情報が正確に伝えられて いないことが多い. 大規模事業場においても組織が分断 され，部署間での情報のやり取りが的確に行われていな ければ，同様の状態となっている場合が多く，危険性情 報の把握が不十分である状況は最近の事故発生に共通し ている要因でもある.

製品・プロセスの研究・開発やプラント設備設計時の RA で得られる危険性情報及びそれに対するリスク低減 措置の目的（設計意図）と，その時点で未対応となって いる危険性（残留リスク）に関する情報などを操業現場 で働く作業者にも確実に伝えること（リスクコミュニケ ーション）が重要である. また， 2 章の 5)で述べたよう な変更のマネジメント時の RA の結果とリスク低減措置 の検討・実施に関する情報を記録として残し, 関係する 作業者間で情報共有することも重要である.このような プラントに潜在する危険性情報共有の仕組みは対象とす るプラント設備の危険性に関する感受性を高めることに も貢献する.

\section{4 化学プロセス産業における統合的リスクマネジメ ントに関する検討}

1）リスクマネジメントの進め方

ISO/IEC Guide 51 10)（JIS Z $8051{ }^{11)}$ ) には，RAを 含むリスク低減プロセスが示されているが，具体的なリ スク低減措置の検討・実施については明確には述べられ ていない. 本来, RA 等実施の目的は, 潜在する危険性・ 有害性要因を抽出・評価することと, 適切なリスク低減 措置（ハード面，ソフト面）を検討・実施することであ る.ここでは RA 及びリスク低減措置の検討・実施まで をリスクマネジメントとして捉え, 以下にその進め方を まとめる.

\section{i ）八ザードを抽出（特定）する.}

ある一定の流れ（プロセス, プラント設備, 操作手順 など）に沿った分析を行い，三つの RAの観点から網羅 的にハザードを抽出する.例えば, 作業標準書, SQDC 工 程管理表 12 )などを準備する段階での分析も有用である. ii）ハザード発生頻度, 影響, 及びリスクを見積もる. 現状のリスク低減対策は施されていないものとして,
最悪の事態を踏まえたリスクの見積りを行い, ハザード の存在を明示的にする.

iii）リスク低減措置を検討し, 実施する.

(1) 現状のリスク低減措置の効果を確認する. そのリスク低減措置はどのようなハザードに対して, どのような効果があるのか（ハザードの発生頻度をどこ まで下げることができるのか?， ハザードによる影響を どこまで緩和することができるのか?）を確認する.

(2) 厚生労働省の指針などに示された優先順位に従って 有効なリスク低減措置を検討し, ALARP 領域以下の リスクとなるように, 可能な限りすべてのリスク低減 措置を実施する.

(3) 新規のリスク低減措置について, 次の点を明らかに しておく.

ーどのハザードに対して有効な措置なのか?

一ハザードの発生頻度を下げるための措置か，八ザー ドによる影響を緩和するための措置か，またはその 両方への措置か?

iv）残存リスクを把握し, 現場作業員に意識させる.

(1) 本質安全対策及び工学的対策として実施されたリス ク低減措置については, 現場作業者もその設置理由(設 計意図）を十分に把握するとともに，緊急時に利用さ れることを踏まえて, 常に機能が維持されていること を確認しておく.

(2) 管理的対策と保護具使用はリスク低減措置の一部で あるが，日常業務の中では疎かになる場合が多く，リ スク低減措置として機能していない場合がある.これ を防ぐため，管理的対策と保護具使用が如何にリスク 低減に寄与しているかという重要性を明確にしておく

2) プラントライフサイクルエンジニアリングによる化 学プラント設備のリスクマネジメント

厚生労働省が平成 12 年 3 月に策定した「化学プラン トにかかるセーフティ・アセスメントに関する指針」13) では，化学プラントの試運転開始までに安全性を評価す ることとされている. 一方, 図 2 に示すように化学プラ ントのリスク低減措置 (安全対策) は, 研究・開発から プラントの設計, 建設・工事, 生産（運転・保全）及び プラントの廃㶳を加えたライフサイクル全般にわたるそ れぞれのエンジニアリング段階において実施される ${ }^{12)}$. 労働災害, 健康障害などが発生するのは生産業務開始後 の生産（運転・保全）の現場であるが，その現場におい て取り扱う原材料や製品の物質特性や操業条件を決定す るとともに，作業者一の健康影響や環境への影響を把握 するのは研究・開発段階であり, それらの検討事項に基 づいて実プラントでの安全衛生対策を検討・決定するの は設計段階である. 設計結果を基に建設・工事段階でプ ラント設備が建設され, 現場でさらに様々な調整が図ら れる. 


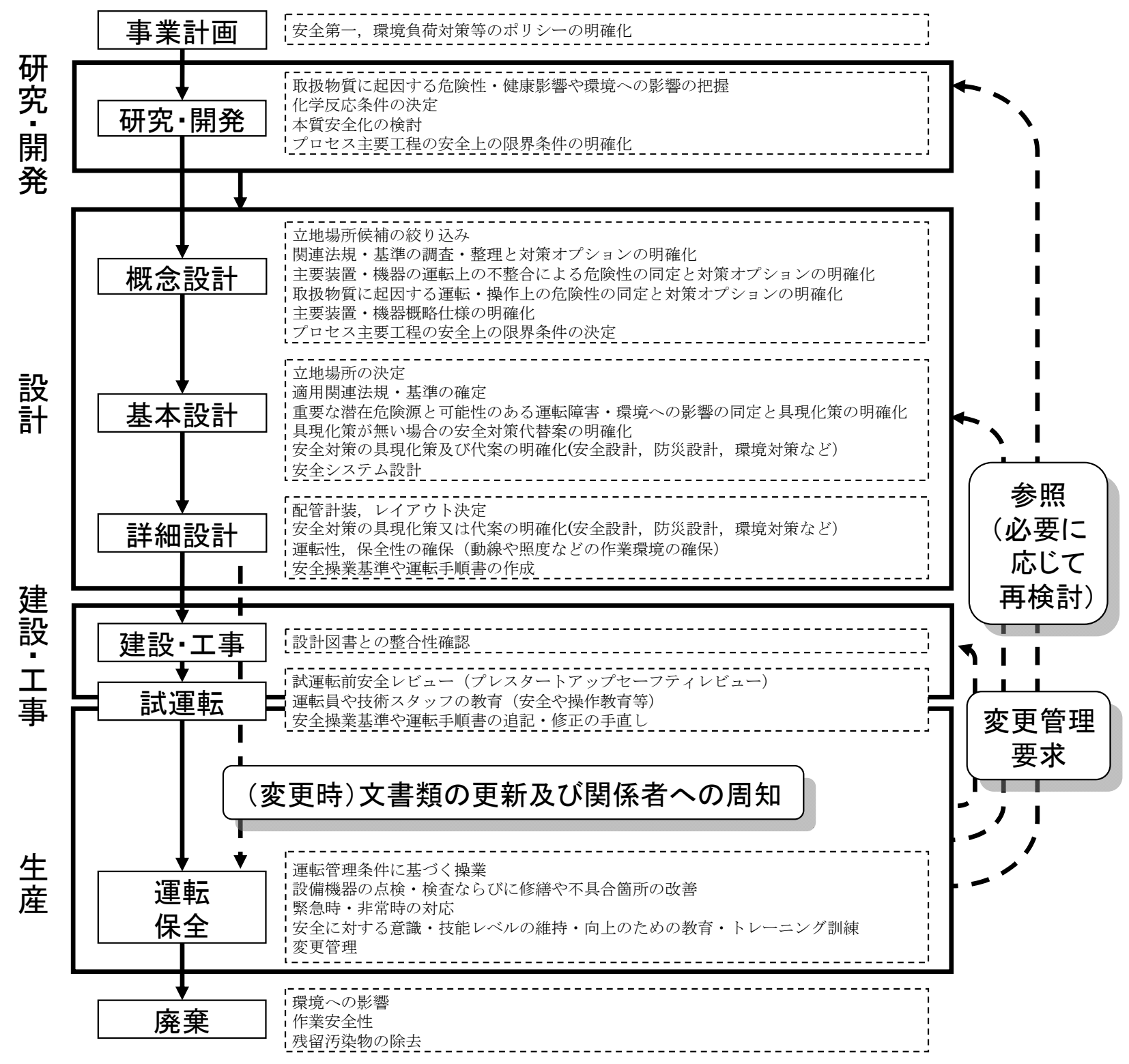

図 2 プラントライフサイクルにわたるリスク低減措置と生産業務実施時の変更管理要求への対応

表 2 プラントライフサイクルの各段階で実施すべき RA 及びリスク低減措置の検討・実施（対象と目的）

\begin{tabular}{|c|c|c|c|c|c|c|c|}
\hline & \multirow[b]{3}{*}{ RAの検討対象と目的 } & \multicolumn{2}{|c|}{$\begin{array}{l}\text { 研究·開発 } \\
\end{array}$} & \multirow{2}{*}{ 設計 } & \multirow{2}{*}{ 建設·工事 } & \multicolumn{2}{|c|}{ 生産 } \\
\hline & & $\begin{array}{c}\text { 研究 } \\
\end{array}$ & \begin{tabular}{|c|} 
開発 \\
\end{tabular} & & & 運転 & 保全 \\
\hline & & $\begin{array}{l}\text { 研究, 開発，設 } \\
\text { 計, 運転·保全 }\end{array}$ & $\begin{array}{l}\text { 開発設設誥, } \\
\text { 連䖝保全 }\end{array}$ & $\begin{array}{c}\text { 設計, 建設·I } \\
\text { 事. }\end{array}$ & 建設·工事 & 運転·保全 & 運転·保全 \\
\hline \multirow{2}{*}{$\begin{array}{l}\text { 化学物啠RA } \\
\text { 物質特性, 反応特性, 毒性評 }\end{array}$} & $\begin{array}{l}\text { 対象物質(検討候補も含む) } \\
\text { 汇関寸安全 }\end{array}$ & 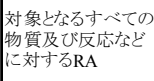 & 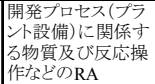 & 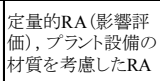 & 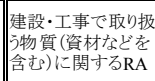 & \multicolumn{2}{|c|}{$\begin{array}{l}\text { 対象プラント設備で取り扱われる物質に } \\
\text { 対するRA }\end{array}$} \\
\hline & $\begin{array}{l}\text { (建設·工事, 生産へのRA } \\
\text { 結果情報の伝共有) }\end{array}$ & & & & 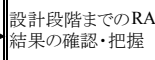 & \multicolumn{2}{|c|}{ |建設・工事段階までのRA結果の碓譙·把 } \\
\hline \multirow{2}{*}{$\begin{array}{l}\text { 設備RA } \\
\text { (対象機器, プラント設備, プロ } \\
\text { セス, オベレーション) }\end{array}$} & $\begin{array}{l}\text { 対象プラント設備(検討候補 } \\
\text { も含む)に関する安全 }\end{array}$ & 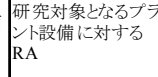 & $\begin{array}{l}\text { 開發刘象となるプラ } \\
\text { 設請に対する } \\
\text { RA }\end{array}$ & 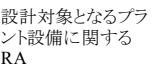 & 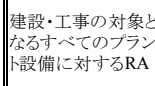 & \multicolumn{2}{|c|}{ |対象プラント設備のRA } \\
\hline & $\begin{array}{l}\text { (建設·工事, 生産へのRA } \\
\text { 結果情報の佉垬·有) }\end{array}$ & & & & 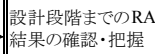 & \multicolumn{2}{|c|}{ |建設・土事段階までのRA結果の確認·把 } \\
\hline \multirow{3}{*}{$\begin{array}{l}\text { 作業安全RA } \\
\text { (作業形態, 作業環境) }\end{array}$} & $\begin{array}{l}\text { 各段階の作業者に対する労 } \\
\text { 譈炎防止 }\end{array}$ & 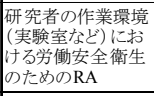 & 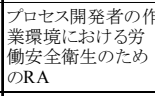 & 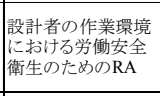 & 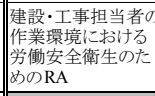 & \multicolumn{2}{|c|}{ 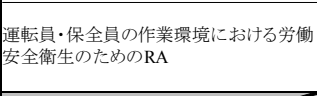 } \\
\hline & 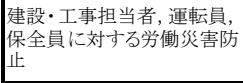 & 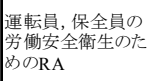 & $\begin{array}{l}\text { 運転吕, 保全員の } \\
\text { 哑安全衛生のた }\end{array}$ & 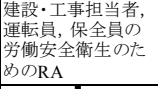 & & & \\
\hline & $\begin{array}{l}\text { (建設·工事, 生產へのRA } \\
\text { 結果情報伝迋·共有) }\end{array}$ & & & & $\begin{array}{l}\text { 設計段階までのRA } \\
\text { 結果の確認·把握 }\end{array}$ & \multicolumn{2}{|c|}{ |建設・土事段階までのRA結果の確認·把 } \\
\hline
\end{tabular}


表 2 にプラントライフサイクルの各段階で実施すべき 三つの RA の対象と目的を示す ${ }^{3}$.

研究・開発段階では, 開発プロセスに関係する物質, 反応操作などの化学物質 RA を実施するともに, パイロ ットプラントなどの建設・工事を視野に入れた設備 RA も実施する.さらに研究者やプロセス開発者の作業環境 だけでなく，建設・工事及び生産時の作業者の作業環境 を想定した作業安全 RA を実施する.

設計段階では, 原材料, 触媒などによる爆発・火災発 生を想定した定量的影響評価などの化学物質 RA と, 八 ザード発生時のリスク低減措置の検討・実施を含む安全 設計のための設備 RA（HAZOP など）を実施する。ま た，設計者の作業環境だけでなく，建設・工事及び生産 時の作業者の安全を確保する為の作業安全 RA も実施す る.

建設・工事段階では, 取り扱う資材などに関する化学 物質 RA を実施することで, 火災・爆発の発生などを防 ぐだけでなく, 対象となるプラント設備の設備 RA, 建 設機器や使用する工具などを使用する際の安全確保を目 的とした作業安全 RA も実施する。 また，建設・工事時 には，研究・開発及び設計段階で得られている危険性・ 有害性情報を把握し, 対象となる化学プロセス, プラン 卜設備の取り扱いにも注意する.

生産（運転・保全）段階では, 研究・開発及び設計段 階で実施された化学物質 RA, 設備 RA の検討内容（ど のようなハザードの発生を想定し, それに対してどのよ うなリスク低減措置が実施されているか?）を十分に把 握するとともに, 関係する運転員, 保全員などが作業を 行う現場についての作業安全 RA を実施する。 また 2 章 の 5)で述べたように, 運転・保全時に何か不具合が発生 する又は変更を実施する場合（運転や保全段階から変更 が要求された場合）には, 必要に応じて, 研究・開発ま たは設計段階にまで遡り， RA 等を再度実施する.

以上のように，それぞれのエンジニアリング段階での 対象に合わせて三つの RA 及びリスク低減措置の検討・ 実施を統合的に実施することで化学プロセスにおける労 働災害及びプロセス災害を防止するためのリスク低減措 置を検討・実施することができる.

\section{3）統合的なリスク低減措置の検討及び実施}

化学物質等による危険性又は有害性等の調査等に関寸 る指針は，主に作業者の安全確保の面から示されたもの である。一方, AIChE/CCPS が提唱した独立防御層 (IPL ; Independent Protection Layer) は化学プラン 卜の安全設計を体系的に実施するための概念である ${ }^{14)}$. ここでは，これらの組合せにより，化学プラント及び化 学プラントに携わる作業者の安全を確保するためのリス ク低減措置の検討及び実施について改めて整理し, 設計 段階を通じて具体的なリスク低減措置を実現するための 考え方を示す.

\section{（1）独立防御層}

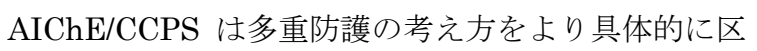
分した独立防御層の概念による設計の根本的な考え方を 提唱している. 図 3 に独立防御層の概念図と各層の目的 及び具体例を示す．独立防御層は多重の独立した防御シ ステム層によりプラント設備を包み込むことで，潜在的 な危険が事故や災害につながることを未然に防ごうとす るものである.また内側の防御層が損なわれたとしても, その外側の防御層が機能することにより，事故を未然に 防ぎ，被害（災害）を最小限に食い止めることを目的と している.各防御層のリスク低減効果と妥当性とを鑑み, 化学プロセス・プラントの安全性だけでなく, 事業場内 外への対応を設計として盛り込むための具体的なリスク 低減措置の実現手段に注目した設計概念である.

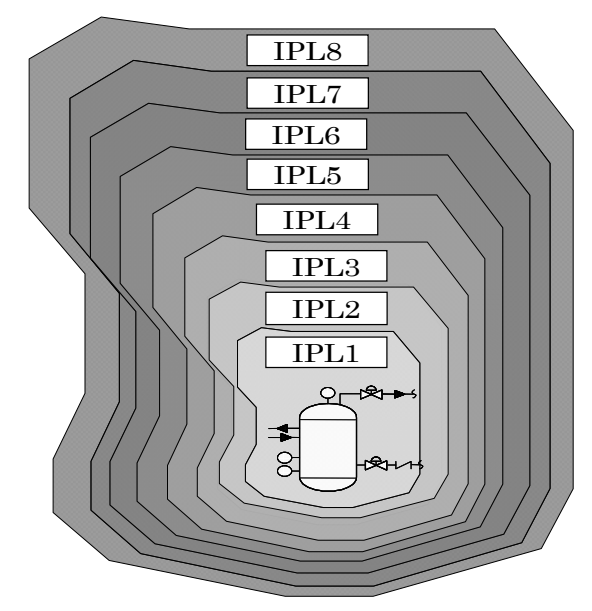

\begin{tabular}{|c|l|}
\hline IPL & \multicolumn{1}{c|}{ 概要 } \\
\hline 1 & プロセス設計 (本質安全) \\
\hline 2 & BPCS, プロセスアラーム, 操作員監視 \\
\hline 3 & $\begin{array}{l}\text { クリティカルアラーム } \\
\text { (操作員監視と割り込み操作) }\end{array}$ \\
\hline 4 & 自動安全インターロックシステム \\
\hline 5 & 物理的防御（安全弁など） \\
\hline 6 & 物理的防御（防液堤など） \\
\hline 7 & 事業場内の緊急対応計画 \\
\hline 8 & 地域住民・公共設備への緊急対応 \\
\hline
\end{tabular}

図 3 独立防御層

\section{（2）厚生労働省指針と独立防御層の関連付け（労働安 全衛生とプロセス安全)}

化学プロセス産業の事業場・プラントの現場改善に繋 がる論理的なリスク低減措置を検討するための RA 等 の進め方の枠組みについて提案する. 図 4 に厚生労働省 の指針と独立防御層によるリスク低減措置検討の関係を 示す.

3 表 2 は検討中のものである.

Vol. 6, No.2, pp. 67-75, (2013) 


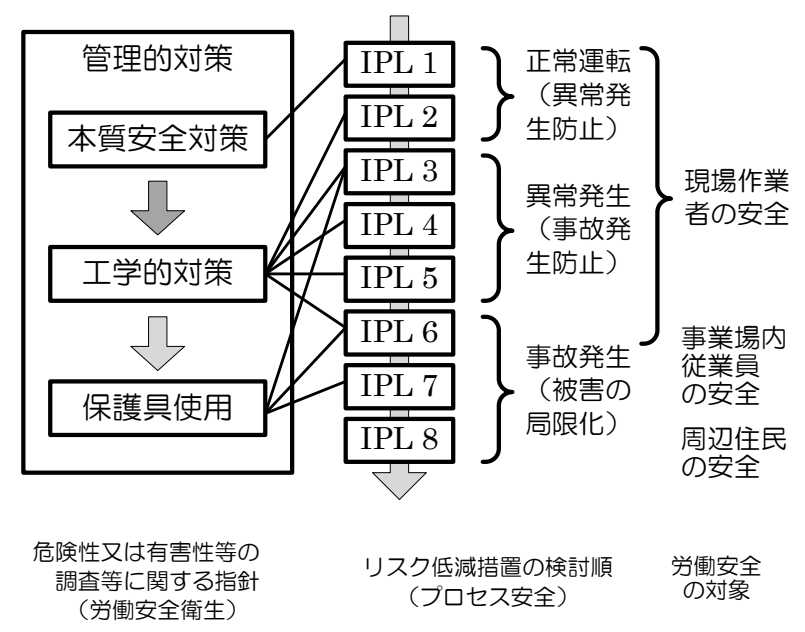

図 4 厚生労働省指針と独立防御層によるリスク低減措置 検討の関係

「本質安全対策」は最優先事項であり，独立防御層で も IPL 1 に位置付けられている. 危険物質の代替や触 媒・溶媒の選択による低温低圧運転の可能性や危険物質 の帯留時間の短縮化などの検討による安全なプロセスの 採用に加え, 単体機器の健全性設計, 機器の信頼性確保, 誤操作防止設計などにより異常を発生させないようにす る.

「工学的対策」は独立防御層では，おもに IPL $2 \sim 6$ に相当する. 正常運転（通常作業）における安全を確保 するための IPL 2 , 異常発生時への対応となる IPL $3 \sim 5$, 漏洩物の拡散などを防ぐための IPL 6 の対策を RA の結 果を基にバランスよく実施することが重要となるＩPL 3 は異常発生時に運転員（作業者）の介入により対処す ることを目的としているが，異常発生に伴う影響の大き さを的確に評価し，作業者の安全確保を第一に考えた上 で, IPL 4 及び IPL 5 の工学的対策が必要となる.

「個人用保護具の使用」については独立防御層の概念 では明確に示されていないが，IPL3，6，7 において，作 業者の労働災害防止のための最終手段であることを明示 した上で着用を義務付けることが重要である.

「管理的対策」には，緊急時対応を含めたプラント運 転マニュアルやプラント保守点検のための管理基準の整 備, 本質安全対策の意図把握や個人用保護具の確実な着 用などが含まれ, IPL 1〜 6 のすべてに共通する対策であ る.また，指針では明確に示されていないが，IPL 7 及 び IPL 8 は事業場内外への被害を軽減するために必要な 措置であり, マニュアルの作成や組織の構築だけでなく， 定期的な訓練なども含めて実施しておく.

独立防御層の考え方では，基本的に何らかの異常が発 生した際に，その被害を最小限に留めるための防御のあ り方を論じている. そのため, IPL 1〜8のすべての防御 層を独立に備えることが基本方針となる．その観点から は厚生労働省の指針の四つの対策は，それらのうちのど れかひとつを備えれば良いということではなく，四つの 対策をすべてとりつつ，さらにそれぞれの対策も複数の
独立した手段・措置によって実現することが望ましいと 捉えるべきである。

\section{5 おわりに}

本稿では, 化学プロセス産業（石油，石油化学，化学 などを含む）の操業現場を対象として，RA とリスク低 減措置の検討・実施に関する課題を整理するとともに, 労働災害及びプロセス災害防止に寄与する RA とリスク 低減措置の検討・実施の統合的な実施方法及び潜在する 危険性・有害性の情報共有に関する課題についてまとめ るとともに，プラントライフサイクルエンジニアリング よる統合的リスクマネジメントの進め方の検討について 報告した。

RA 及びリスク低減措置の検討と実施は，事故・災害 発生を未然に防止するための手段であり，これらを的確 に実施することにより，労働災害及びプロセス災害を未 然に防ぐ，または被害を軽減することに貢献する。平成 18 年の改正労働安全衛生法施行以降, RA についての重 要性は認められるようになっているが，化学プロセス産 業において，リスク低減措置の検討・実施までを含めて 的確に実施するためには，多くの課題が残されている. 今後は 4 章で述べた考え方を基に，より有用な RA 等の 手法を確立するための議論を続ける.

\section{文献}

1）若倉正英. 最近の化学事故と安全文化. Safety \& Tomorrow. 2013; 147: 21-27.

2) Kletz T. What went wrong?, $5^{\text {th }}$ ed.. IChemE; 2009.

3）厚生労働省告示第 113 号. 労働安全衛生マネジメントシス テムに関する指針。平成 18 年 3 月 10 日改訂. 2008 .

4）厚生労働省. 平成 22 年労働安全衛生基本調查の概況; 2011.

5）演田勉. 主なき安全〜リスクアセスメントの暴走〜. 労働 調查会 ; 2010 .

6） OHSAS 18002 : 2008. 労㗢安全衛生マネジメントシステ ム-OHSAS18001:2007 実施のための指針．日本規格協 会 ; 2011.

7) Occupational Safety and Health Administration, 29CFR 1910.119. Process Safety Management of Highly Hazardous Chemicals; 1992.

8) $\mathrm{AIChE/CCPS}$. Guidelines for Management of Change for Process Safety. WILEY; 2008.

9）化学工学会安全部会. 変更管理のあり方を探る. 化学工学 テクニカルレポートNo.43；2012.

10) ISO/IEC Guide51; 1999. Safety aspects - Guidelines for their inclusion in standards; 1999.

11）JIS ハンドブック(36)安全 (基本)．JIS Z 8051 : 2004 (2008 確認）。安全側面一規格一の導入指針．日本規格協会； 2010 : 85-91.

12）労㗢安全衛生総合研究所技術資料. 生産業務と安全管理業 務との協調による労働安全衛生マネジメントの推進. 労働 安全衛生総合研究所 ; 2011 : JNIOSH-TD.No.1. 
13）厚生労働省基発第 149 号. 化学プラントにかかるセーフ ティ・アセスメントに関する指針 ; 2000.

14) AIChE/CCPS. Guidelines for Engineering Design for Process Safety. Wiley; 1993: 9-10.

\section{用語の定義}

プロセス安全 : 危険物質を取り扱うプロセス（プラント）にお ける異常や火災，爆発，漏洩などの事故の発生を防止すると ともに，事故が発生した場合にその被害を最小限に抑えるた めの方策も検討する.
プロセス災害 : 爆発，火災，漏洩などにより，事業場及び周辺 地域を含むプラント・設備などに損傷を与えることをいう。

作業安全 : 運転員, 保全員などの作業者が作業をする環境にお いて，転落や滑り，はさまれ，巻き込まれなどを防止するた めのリスク低減措置などについて検討する.

労働災害 : 労働者の就業に係る建設物, 設備, 原材料, ガス, 蒸気, 粉じん等により, 又は作業行動その他業務に起因して, 労働者が負傷し，疾病にかかり，又は死亡することをいう。

\title{
Investigation Study on Risk Assessment and Implementation of Risk Controls in The Chemical Process Industries
}

by

\author{
Yukiyasu SHIMADA ${ }^{* 1}$, Teiji KITAJIMA ${ }^{* 2}$ and Arata KIMURA ${ }^{* 3}$
}

The purpose of risk assessment (RA) is the determination of a quantitative and/or qualitative value of risk related to a concrete situation and a recognized hazard. The results of it are used to consider risk controls for preventing occupational and process accidents. The number of workplaces which carry out RA is increasing under administrative measures for industrial disaster prevention based on RA. However, it is most often the case that the original purpose of RA are not understood correctly and truly effective risk controls based on the appropriate risk estimation are not implemented.

We focused on the workplaces in the chemical process industries (petroleum refinery, petroleum chemical, chemical, etc.) and carried out a hearing investigation and held a discussion with safety experts. The current states and issues, which are related to the RA and the implementation of risk controls, and the subjects of risk information sharing through the life-cycle of a chemical process plant were clarified. For these issues and subjects, we propose a tentative integrated approach to RA and the implementation of risk controls for preventing occupational and process accidents.

Key Words: risk assessment, risk control, occupational safety, process safety, independent protection layer

*1 Chemical Safety Research Group, National Institute of Occupational Safety and Health

*2 Institute of Engineering, Tokyo University of Agriculture and Technology

*3 Maritime Risk Assessment Department, National Maritime Research Institute 